Research Article

\title{
The Interest of Young Agricultural Entrepreneurs (Young Farmers) on Chili Agribusiness in Kabupaten Garut
}

Ait Maryania1*, Dedy Kusnadib2, Wida Pradianac3

abc Agricultural Development Polytechnic, Ministry of Agriculture, Bogor, Indonesia

Jalan Aria Surialaga, Nomor 1, Bogor, West Java, Indonesia

Email: 1aitmaryanistpp@gmail.com, ${ }^{2}$ dedyasgar57@gmail.com, ${ }^{3}$ widaprstpp75@gmail.com

* corresponding author

\begin{tabular}{|c|c|}
\hline ARTICLE INFO & ABSTRACT \\
\hline $\begin{array}{l}\text { Article history } \\
\text { Received February 22, } 2021 \\
\text { Revised September 28, } 2021 \\
\text { Accepted October 14, } 2021 \\
\text { Published October 26, } 2021\end{array}$ & $\begin{array}{l}\text { The study aims at analyzing the descriptions of the interests of young agricultural } \\
\text { entrepreneurs (young farmer) and discovering the factors affecting their interest in chili } \\
\text { agribusiness. The study was conducted in Kabupaten Garut from June to November, } \\
2019 \text {. This study employs a quantitative approach. In this study, population was } 1.376 \\
\text { of young agricultural entrepreneurs (young farmer) aged under } 40 \text { in chili production } \\
\text { centers. Sample for this study was } 233 \text { people obtained by calculating following Slovin. } \\
\text { The samples were scattered in sub-district of Banyuresmi ( } 79 \text { people), Wanaraja (72 } \\
\text { people) and Cikajang (83 people). Sampling technique employed was proportional } \\
\text { random sampling. Primary data were collected from respondents through direct } \\
\text { interviews and focus group discussion (FGD). The research variables consisted of } \\
\text { individual characteristics, external characteristics, and the interests of young agricultural } \\
\text { entrepreneurs (young farmer). The collected data were analyzed by utilizing descriptive } \\
\text { statistical analysis and multiple regression. The results of the study concluded show } \\
\text { that most of the respondents stated their interest were at a moderate level. The average } \\
\text { age of young agricultural entrepreneurs (young farmer) is } 31.47 \text { years. The majority are } \\
\text { still elementary school educated, and most of them have never been involved in } \\
\text { organizations and never joined apprenticeship/courses/training. However, cosmopolitan } \\
\text { attitude is in the high category. The interest of young agricultural entrepreneurs (young } \\
\text { farmer) is affected by institutional, non-formal education, cosmopolitan and external } \\
\text { factors including government support, availability of infrastructure, agricultural } \\
\text { extension, easy access to information, community leaders and production markets. }\end{array}$ \\
\hline
\end{tabular}

Copyright (C) 2021, Maryani et al This is an open access article under the CC-BY-SACC-BY-SA license

\section{INTRODUCTION}

Agriculture is still the main sector for rural communities. Agriculture as the main livelihood has become a source of income and reduces unemployment, especially for the younger generation in rural areas. Employment opportunities for the young generation in agriculture in the rural areas are wide open, and the 
young generation are expected to play a role in agricultural development in the future. However, based on previous research, the younger generation's interest in agricultural activities has decreased (Ningsih \& Sjaf, 2015). Research by Wiyono et al. (2015) reported on several issues concerning the interest of the younger generation. Most of the younger generation are not interested in being rice farmers $(70 \%)$ or horticulture (73.3\%). Some young farmers who have been engaged in agriculture said they were forced to become farmers because there were no other options (jobs).

The decline in the interest of the younger generation to pursue agriculture is suspected to be the cause of the decline in the number of agricultural actors. It can be proven by the percentage of the population in Indonesia who are engaged in agriculture tends to experience depreciation. Based on information from the agricultural census results, the distribution of farmers in 2003 was 55.7 percent, then in 2013, it decreased to 40.81 percent (Anwarudin et al., 2019; Dayat et al., 2020). Next, in 2018, the share of farmers was reported to be 31.90 percent (Statistics Indonesia (BPS), 2018). The results of the information comparison according to that period show that agricultural actors are experiencing an extreme decline.

Based on the preliminary survey, in several areas in Kabupaten Garut, it is discovered that many young people are engaged in agriculture. This young farmer is active in chili agribusiness. Garut is a substantial chili producing area in West Java. Chili is a strategic commodity that has been unable to meet national needs. Kabupaten Garut can supply 30 to 40 percent of chili needs of Jabodetabek.

Some researchers report that young farmers who have successfully engaged in agriculture tend to possess good interests. Successful agropreneurs in Cianjur have a high interest in agriculture (Harniati \& Anwarudin, 2018b). Anwarudin \& Haryanto (2018) recommends the importance of the role of government and nongovernmental agricultural extension officials to involve the younger generation in extension and agricultural activities so that the gradual regeneration of farmers can be realized. Harniati \& Anwarudin (2018) support these reports and recommendations by proving that most of the young farmers who are currently engaged in agriculture are the result of informal education. For instance, it is because parental involvement in agriculture; it is because they are interested in and follow the examples of successful advanced farmers; it is because of independent extension officials; and they are members of young farmer communities. This study aims at analyzing the extent to which young farmers are interested and discovering the factors affecting the young farmers' interest in chili agribusiness in Kabupaten Garut.

\section{RESEARCH METHODS}

This study was conducted in Kabupaten Garut from June to November 2019. This study employs a quantitative approach. The population of this study is 1376 young agricultural entrepreneurs (young farmers) aged under 40. A sample of 233 people was obtained through calculations following Slovin with an error rate of $6 \%$. The samples are spread over several sub-districts: Banyuresmi (79 people), Wanaraja (72 people) and Cikajang (83 people). Samples were determined and selected based on proportional random sampling technique. Research data includes primary and secondary data. Primary data were obtained from respondents through direct interviews and focus group discussions (FGD). The research instrument used a questionnaire that had been tested for its validity and reliability with results showing it is valid and reliable.

The research variables consisted of: individual characteristics (X1), external support (X2), and interest of a young agricultural entrepreneurs (young farmers) $(Y)$. Individual characteristics (X1) are defined as distinguishing characteristics (identifiers) with other individuals, consisting of: age $\left(X_{1.1}\right)$, formal education $\left(X_{1.2}\right)$, non-formal education $\left(X_{1.3}\right)$, organizational experience $\left(X_{1.4}\right)$, and cosmopolitan $\left(X_{1.5}\right)$. External characteristics (X2) are components coming from outside the individual, consisting of: farmer group support $\left(X_{2.1}\right)$, availability of infrastructure $\left(X_{2.2}\right)$, government support $\left(X_{2.3}\right)$, ease of access to information $\left(X_{2.4}\right)$, extension activities $\left(X_{2.5}\right)$, support from community leaders $\left(X_{2.6}\right)$, and market availability $\left(X_{2.7}\right)$. Interest of a young agricultural entrepreneurs (young farmers) $(Y)$ is defined as the motives of the young agricultural

76

Ait Maryani et.al (The Interest of Young Agricultural Entrepreneurs..., Young Farmer, Farmer Regeneration Chili Agribusiness) 
entrepreneurs (young farmers) to participate in agricultural activities, which are determined by: willingness to own a business $\left(Y_{1.1}\right)$, become a successful entrepreneur $\left(Y_{1.2}\right)$, and become a independent extension officials $\left(Y_{1.3}\right)$. The data obtained were then analyzed according to the research objectives. To explain the interest of the young agricultural entrepreneurs (young farmers) like individual characteristics and external characteristics, descriptive statistical analysis was conducted. Multiple regression analysis was used to determine the factors affecting the interest of the young agricultural entrepreneurs (young farmers).

\section{RESULTS AND DISCUSSION}

\section{Description of Research Variables}

Individual characteristics of a young agricultural entrepreneurs (young farmers) in this study include age, formal education, non-formal education, organizational experience and cosmopolitan. The average age of them is 31.47 years. The youngest of young agricultural entrepreneurs (young farmers) engaging in agriculture is 16 years old, a relatively young age to be a worker or entrepreneur. Their involvement in agriculture is actually even younger than 16. Based on in-depth interviews, several young agricultural entrepreneurs (young farmers) have been involved in agricultural cultivation since school-age children. Most of the young agricultural entrepreneur (young farmers) started their farming activities by helping their parents in the family's farm and rice fields. They help their parents' farming business even if it is only modest or not full, even considered light agricultural activities (the level of activity is according to their parents' considerations). Some of these agricultural activities include planting, fertilizing and watering. Some young agricultural entrepreneur (young farmers) starts full-fledged farming after getting married or starting their own families. The results of interviews and observations found that the young agricultural entrepreneurs (young farmers) have greater responsibilities when they are married. Some parents give their children part of their agricultural land when their children get married. The land is intended as a means of earning a living so that the married children can fulfill their life needs independently and be separated from their parents.

The education of most of the young agricultural entrepreneurs (young farmers) is in the level of elementary, and some are junior high school, senior high school and Higher education (go to college). Therefore, all young agricultural entrepreneurs (young farmers) can read and write. When compared with the level of education of farmers in general, which is elementary (Qintamy et al., 2020; Hamdana et al., 2020; Maryani et al., 2020a), the portion of young agricultural entrepreneurs (young farmers) with this level of education is much smaller. This shows that the level of education of young agricultural entrepreneurs (young farmers) is better than that of general or adults' farmers. The results of this study are in line with previous studies (Dayat et al., 2020; Wardani \& Anwarudin, 2018), yet it is different from Harniati \& Anwarudin (2018) reporting that the majority of young farmers who are members of the agricultural entrepreneur community have education level at junior and senior high school. 
Table 1. Individual characteristics of young agricultural entrepreneurs (young farmers) based on age, formal education, involvement in organizations, non-formal education and cosmopolitan attitude

\begin{tabular}{|c|c|c|c|}
\hline No. & Category & Total of Respondent (person) & Percentage (\%) \\
\hline \multicolumn{4}{|c|}{$\mathrm{X}_{11}$ Age of young agricultural entrepreneurs (young farmers) (year) } \\
\hline 1. & $16-20$ & 15 & 6.44 \\
\hline 2. & $21-25$ & 36 & 15.45 \\
\hline 3. & $26-30$ & 58 & 24.89 \\
\hline 4. & $31-35$ & 65 & 27.90 \\
\hline \multirow[t]{2}{*}{5.} & $\geq 36$ & 59 & 25.32 \\
\hline & \multicolumn{3}{|c|}{ Average: 31,47 years } \\
\hline \multicolumn{4}{|c|}{$X_{12}$ Formal education } \\
\hline 1. & Elementary School & 89 & 38.20 \\
\hline 2. & Junior High School & 68 & 29.18 \\
\hline 3. & Senior High School & 60 & 25.75 \\
\hline \multirow[t]{2}{*}{4.} & Higher Education & 16 & 6.87 \\
\hline & \multicolumn{3}{|c|}{ Modus: Elementary School } \\
\hline \multicolumn{4}{|c|}{$\mathrm{X}_{13}$ involvement in organizations/farmer organization } \\
\hline 1. & Never & 203 & 87.12 \\
\hline 2. & $1-5$ years & 25 & 10.73 \\
\hline \multirow[t]{2}{*}{3.} & $\geq 5$ years & 5 & 2.15 \\
\hline & \multicolumn{3}{|c|}{ Modus: Not yet accommodated by young agricultural entrepreneur (young farmer) communit) } \\
\hline \multicolumn{4}{|c|}{$\mathrm{X}_{14}$ Non-formal education (workshop, internship) } \\
\hline 1. & Never & 221 & 94.85 \\
\hline 2. & $1-3$ days & 10 & 4.29 \\
\hline \multirow[t]{2}{*}{3.} & $\geq 4$ days & 2 & 0.86 \\
\hline & \multicolumn{3}{|c|}{ Modus: Never join a course/ an internship (non-formal education) } \\
\hline \multicolumn{4}{|c|}{$\mathrm{X}_{15}$ Cosmopolitan attitude } \\
\hline 1. & Low & 10 & 4.3 \\
\hline 2. & Moderate & 86 & 36.9 \\
\hline \multirow[t]{2}{*}{3.} & High & 137 & 58.8 \\
\hline & Average: 36 (High) & & \\
\hline
\end{tabular}

Most of the young agricultural entrepreneurs (young farmers) have not been involved in farmer groups. Therefore, according to the recommendations from Dayat et al. (2020), young farmers must be motivated and involved in existing farmer groups. In the three sub-districts where the research was located, Banyuresmi, Wanaraja and Cikajang, only one group of young agricultural entrepreneurs (young farmers) was found, the other was an adult farmer group. Young agricultural entrepreneurs (young farmers) who have never attended internships, training/workshop and courses are many. It is in line with the report written by Anwarudin et al. (2019). However, most of the young agricultural entrepreneurs (young farmers) reflected a high cosmopolitan attitude. This means they have high relationships and access to outside the village. It can encourage young agricultural entrepreneurs (young farmers) to get information and experience more quickly from sources other than where they live. Some information obtained by young agricultural entrepreneurs (young farmers) is the types or varieties of chili seeds, planting techniques, fertilization, disease management and selling prices as well as where to sell their crops at better prices.

The external support of young agricultural entrepreneurs (young farmers) studied in this study is the support of farmer groups, availability of facilities and infrastructure, government support, ease of access to 
information, intensity of agricultural extension, support from community leaders, and market availability. The results of the descriptive statistical analysis of external support are presented in Table 2.

Table 2. External support of young agricultural entrepreneurs (young farmers) by category

\begin{tabular}{llll}
\hline No. & Category & Total of Respondent (person) & Percentage (\%) \\
\hline 1. & Low & 76 & 32.62 \\
2. & Middle & 145 & 62.23 \\
3. & High & 12 & 5.15 \\
\cline { 2 - 4 } & Total & 233 & 100 \\
\cline { 2 - 4 } & Average & $: 94.67$ (Moderate) & \\
\hline
\end{tabular}

Most young agricultural entrepreneurs (young farmers) have moderate level of external support. External support for young agricultural entrepreneurs (young farmers) having been felt is government support, availability of infrastructure, intensity of agricultural extension, easy access to information, community leaders and production markets. Government support for young agricultural entrepreneurs (young farmers) has been carried out through training/workshop. The material having been delivered is in the form of technical and entrepreneurial aspects. Some other programs are internship facilitation and tool assistance. However, the program has only reached a few young agricultural entrepreneurs (young farmers). Government support pays more attention to adult farmers who already have farmer groups. Therefore, the government must pay attention to young agricultural entrepreneurs (young farmers) with the support of business capital and infrastructure because it can be an incentive to grow and develop a business in accordance with the report Anwarudin (2021).

Most young agricultural entrepreneurs (young farmers) have not been involved in agricultural extension activities. Extension activities have been routinely carried out, but they have not made young agricultural entrepreneurs (young farmers) the target of counseling. Agricultural extension is mostly intended for adult farmers. In the activities of fostering farmer groups, agricultural extension officials more often foster adult farmer groups whose members are elderly farmers. Therefore, agricultural extension officials must play an optimal role by starting to pay attention to young agricultural entrepreneurs (young farmers) as the targets of the extension in addition to adult farmers because young agricultural entrepreneurs (young farmers) will be the successors of their parents who are member of adult farmers group (Dayat \& Anwarudin, 2020b). Through agricultural extension, it is hoped that young farmers can improve their knowledge, attitudes, skills, (Pradiana et al., 2020),business capacity and entrepreneurial spirit (Anwarudin et al., 2020a).

The next external factor is the support of the production market. The market has helped young agricultural entrepreneurs (young farmers) a lot. Some information regarding the production market is needed, such as information on selling prices, consumers and the volume of demand for commodities. The availability of a production market opens up business opportunities for young agricultural entrepreneurs (young farmers). The market is a place for young agricultural entrepreneurs (young farmers) to sell agricultural products, as well as the place for buying seeds and fertilizers. Busy markets can stimulate the businesses potency of young agricultural entrepreneurs (young farmers) to be sustainable (Anwarudin et al., 2020b). Through smooth market information, young agricultural entrepreneurs (young farmers) become good at identifying business opportunities (Dayat \& Anwarudin, 2020a), and developing businesses to be more advanced (Anwarudin et al., 2020d). 
Table 3. Interest of young agricultural entrepreneurs (young farmers) by category

\begin{tabular}{llll}
\hline No. & Category & Total of Respondent (person) & Percentage (\%) \\
\hline 1. & Low & 25 & 10.73 \\
2. & Moderate & 106 & 45.49 \\
3. & High & 102 & 43.78 \\
\cline { 2 - 4 } & Total & 233 & 100 \\
\cline { 2 - 4 } & Average & $: 57.5$ (Moderate) & \\
\hline
\end{tabular}

All young agricultural entrepreneurs (young farmers) have an interest in agriculture. Their interests vary from low, moderate to high. Previous research on the interests of the younger generation has so far yielded mixed results. This study shows that most of the young agricultural entrepreneurs (young farmers) have an interest in the moderate category. However, this result is different from previous research conducted on the younger generation which found that their interest was in the low category (Wiyono et al., 2015). Another study conducted on young agricultural entrepreneurs found that their interest in working in the agricultural sector was high (Harniati \& Anwarudin, 2018b). The difference between the results of this study and the research was caused by the research respondents. In this study, the respondents were young agricultural entrepreneurs (young farmers) of chili in rural areas, while in research by Wiyono et al. (2015), the respondents were younger generation who did not have an agricultural business. In addition, previous research by (Harniati \& Anwarudin, 2018b) , the respondents were young agricultural entrepreneurs who were relatively advanced.

Furthermore, related to young agricultural entrepreneurs (young farmers) who already have an interest in doing business in agriculture and are in the medium category, they need to be appreciated. This situation reflects the emergence of the younger generation to start a business in agriculture. This condition is allegedly also supported by the better perception of the younger generation on agribusiness as reported by Anwarudin \& Dayat (2019) and Nazaruddin \& Anwarudin (2019) writing that farmers began to have a good perception. Young agricultural entrepreneurs (young farmers) in Kabupaten Garut have started having a good perception of all agribusiness sub-systems, both upstream, farm, downstream and supporting. For the upstream subsystem, young agricultural entrepreneurs (young farmers) feel the importance of providing production facilities for chili agriculture. Some production facilities obtained from suppliers are chili seeds, fungicides, fertilizers, pesticides, and agricultural equipment like hoes. Young agricultural entrepreneurs (young farmers) feel their farming business is hampered when the production facilities for chili agriculture are unavailable at the production facilities provider. Therefore, communication links between young agricultural entrepreneurs (young farmers) and providers of production facilities began to be established and built. For the marketing sub-system, young agricultural entrepreneurs (young farmers) note the importance of chili prices at harvest time. Young agricultural entrepreneurs (young farmers) admit the price of chili is very volatile. The profits obtained by young agricultural entrepreneurs (young farmers) are comparable to the price of chili. When prices are low, young agricultural entrepreneurs (young farmers) also tend to suffer losses. Even, if the chili plants are unharvested because the harvest costs incurred are higher than the harvest income received. Based on the experience of low prices of chili at certain times, farmers perceive the importance of the chili processing sub-system. Currently, there is no chili processing process, meaning that young agricultural entrepreneurs (young farmers) directly sell their harvested chili through collectors, middlemen or directly to the market.

The rise of the younger generation as indicated by the increasing interest in chili agribusiness is good news for the sustainability of agricultural actors. This is related to several facts from 2003 to 2013 indicating the decline in the regeneration of agricultural actors in Indonesia. Indonesian Statistics (BPS) (2013) shows that the portion of young agricultural entrepreneurs (young farmers) is far below the portion of elderly farmers. The distribution of farmers by age category consisting of ages over $54,35-54$ and under 35 years, respectively, is 
32.76 percent, 54.37 percent, and 12.87 percent. This information shows that agricultural actors in Indonesia are dominated by elderly farmers. When the three age groups are compared, it turns out those agricultural actors aged above 54 years (32.76 percent) indicating more significant percentage than agricultural actors aged under 35 years (12.87 percent). Furthermore, It compares the data of BPS from 2003 and 2013 regarding households of agricultural actors. In 2003 , the data presented households with agricultural actors as many as $31,232,184$ or 55.73 percent of the total $56,041,000$ households. Meanwhile, in 2013 , the data shows there are 26,135,469 households engaged in agriculture or 40.81 percent of the total $64,041,200$ households. Based on the comparison between the statistical data in 2003 (BPS 2003) and 2013 (BPS 2013), it is proven that there has been a decline in agricultural actors in the last ten years. The decrease is huge more about 15 percent. If results of the analysis of the data from BPS having been described are not taken seriously, according to Anwarudin et al., (2020c) , they can have an impact on the share of farmers in Indonesia which will more and more decrease.

The interest of young agricultural entrepreneurs (young farmers) in performing good chili agribusiness is driven by the desire to become good agro-preneurs. The result of this study supported by Anwarudin (2020) stating that the interest of the younger generation can grow because they have a passion for entrepreneurship. Therefore, the younger generation should have entrepreneurial capacity including leadership, adaptability, technical ability and the ability to build and foster cooperation (Anwarudin et al., 2020a). Based on field observations, most of the young agricultural entrepreneurs (young farmers) have good adaptability. It is indicated by the use of superior chili seeds. Furthermore, when there is an innovative way of seeding and fertilizing, young agricultural entrepreneurs (young farmers) immediately apply it. Most young agricultural entrepreneurs (young farmers) have technical or agribusiness skills for chili cultivation subsystems obtained from their parents, the agricultural extension officials and their peers. Other agribusiness sub-systems like processing and handling chili products have been uncarried out. One respondent stated he did not have this ability. Activities carried out at this time, the chili harvest is directly sold to collectors and markets. This condition causes young agricultural entrepreneurs (young farmers) to experience difficulties when prices are low. Therefore, the needs of young agricultural entrepreneurs (young farmers) in the technical field that can be identified are handling and processing chili. Another need is mutually beneficial cooperation. Some parties involved are currently limited to collectors, big buyers and traders of agricultural production facilities. Young agricultural entrepreneurs (young farmers) are expected to establish cooperation with more large-scale parties such as instant noodle companies to become suppliers of dry chili powder.

The interest of young agricultural entrepreneurs (young farmers) in good chili agribusiness is prompted by the desire to possess their own advanced agricultural business (agrotechnopreneur). Most young married agricultural entrepreneurs (young married farmers) have their own farming business. The ownership is obtained from the parent's agricultural land grant to the child at the time of marriage. However, for young unmarried agricultural entrepreneurs (young unmarried farmers), they follow their parents in performing chili farming business. This finding is supported by report of Ranzez et al. (2020) and Anwarudin et al. (2020c) stating that parents can play a role in encouraging their children to become farmers through the cultivation of respect, socialization, and grants/inheritance. According to Dayat et al. (2020), the attitude of respect and socialization is shown by the involvement of young agricultural entrepreneurs (young farmers) in supporting their parents' farming business. Some of these agricultural activities include planting, fertilizing, watering and harvesting. Grant or inheritance are carried out by some parents when their children marry by sharing part of their agricultural land. The land is intended as a means of earning a living so that the married children can fulfill their life needs independently and be separated from their parents.

The interest of young agricultural entrepreneurs (young farmers) to pursue chili agribusiness is driven by a sense of togetherness among their friends. One of the choices to be a farmer arises because of the successful farming of peers, and life in the village which is dominated by agriculture. Young agricultural entrepreneurs (young farmers) with their peers and comrades have a habit of sharing stories of success, failure, hindrances, obstacles, and solutions for their handling. For young agricultural entrepreneurs (young farmers), sharing knowledge is not a loss, but it provides them a benefit. It is they encourage each other and 
help their comrades. Young agricultural entrepreneurs (young farmers) have the desire to become successful farmers, and they have much information and relationships to work together. Therefore, they are capable to share with their peers who are pursuing the same business as an advanced farmer who becomes a independent agricultural extension officials.

\section{Factors Affecting the Interest of Young Agricultural Entrepreneurs (Young Farmers)}

Research on the interest of young agricultural entrepreneurs (young farmers) in chili farming in Kabupaten Garut consist of one dependent variable: the interest of young agricultural entrepreneurs (young farmers), and two independent variables: individual characteristics and external factors. Individual characteristics of young agricultural entrepreneurs (young farmers) include age, formal education, organizational experience, non-formal education and cosmopolitan. While external factors are a farmer institutional support, availability of infrastructure, institutional support, easy access to information, extension activities, support from community leaders and availability of production markets. The results of the regression analysis are listed in Table 4.

Table 4 Results of statistical analysis of multiple regression

\begin{tabular}{lll}
\hline Variable & Coefficient & $p$-value \\
\hline $\mathrm{R}^{2}$ & 0.453 & \\
\hline Constanta & 1.543 & 0.764 \\
\hline Age $\left(\mathrm{X}_{11}\right)$ & -0.250 & 0.797 \\
Formal education $\left(\mathrm{X}_{12}\right)$ & 0.354 & 0.092 \\
Organizational experience $\left(\mathrm{X}_{13}\right)$ & 0.956 & 0.028 \\
Non-formal education $\left(\mathrm{X}_{14}\right)$ & 0.922 & 0.039 \\
Cosmopolitan $\left(\mathrm{X}_{15}\right)$ & 0.866 & 0.043 \\
External support $\left(\mathrm{X}_{2}\right)$ & 0.660 & 0.049 \\
\hline
\end{tabular}

Interest of farmers in chili agribusiness is significantly influenced by institutional, non-formal education and cosmopolitan. Other variables having a significant effect on the interest of young agricultural entrepreneurs (young farmers) are government support, availability of infrastructure, agricultural extension, easy access to information, community leaders and production markets. The results of the analysis discovered an R2 value of 0.453 indicating the interest of young agricultural entrepreneurs (young farmers) is affected by the variables in this study by $45.3 \%$, while the rest is affected by other variables. In this study, age and formal education had no significant effect. The results of the regression analysis obtained the following equations:

$Y=0,956 X_{13}+0,922 X_{14}+0,866 X_{15}+0,66 X_{2}$

The study discovered that the involvement of young agricultural entrepreneurs (young farmers) in organizations or institutions had a positive effect on their interest. The higher the involvement, the stronger the interest in working in agriculture. Farmer institutions that are frequently discovered in agricultural communities are farmer groups and association of farmer groups. Most of the young farmers have been uninvolved in the farmer institutions. This is due to the limited existing farmer institutions. In the field, farmer institutions are dominated by adult farmer groups, and specifically there is one farmer group intended for young agricultural entrepreneurs (young farmers). Therefore, some young agricultural entrepreneurs (young farmers) become part of adult farmer groups The study found that the involvement of young agricultural entrepreneurs (young farmers), both male and female in farmer groups, has fostered interest, pleasure and pride in doing farming, as reported Liani et al., (2018). Through farmer group institutions, young agricultural entrepreneurs (young farmers) feel they have friends to ask questions and learn. Through farmer group institutions, young

82 
agricultural entrepreneurs (young farmers) can also develop their businesses and cooperate with other parties. It is in line with farmer groups having a function as a place for learning, production units and a vehicle for working together (Pradiana et al., 2020; Maryani et al., 2020b). It means that the farmer groups have performed their functions well. The problem is that there are still many young agricultural entrepreneurs (young farmers) having not been accommodated by farmer institutions. For those reason, recommendation of Dayat \& Anwarudin (2020b) to related parties to increase the involvement of the younger generation in existing farmer institutions or if possible to encourage the growth of institutions for young agricultural entrepreneurs ( young farmers).

This study recommends that young agricultural entrepreneurs (young farmers) often obtain non-formal education. It is based on the finding that non-formal education such as training, courses and internships has a positive effect on the growth of interest in young agricultural entrepreneurs (young farmers). This study found that the majority of young agricultural entrepreneurs (young farmers) had never attended courses, training and internships, however, their participation in non-formal education had transformed young agricultural entrepreneurs (young farmers) to be interested in farming. It means that non-formal education providers like training centers; non-governmental organizations have a major role in growing the interest of the younger generation in the agricultural sector. Likewise, agricultural companies providing internship opportunities for young farmers have a positive role in attracting the attention of young agricultural entrepreneurs (young farmers) in the agricultural sector. This research has the implication that several government programs regarding internships to advanced farmers outside and within the country should be further improved. The Japanese internship program, for example, has proven that some of its alumni are now farmers. Even, in their groups, they become advanced farmers, head of farmer groups and become managers of agricultural trainings (Anwarudin et al., 2019).

Young agricultural entrepreneurs (young farmers) have characteristics like other younger generations with high curiosity. To get more information, young agricultural entrepreneurs (young farmers) are very close to information and communication technology. In addition, they have a high range of the explorations; they establish many friendships and relationships with other people outside the village. This cosmopolitan attitude turned out to have a positive effect on growing the interest of young agricultural entrepreneurs (young farmers). It means that the higher the activity of farmers seeking information outside their village, the higher the interest of young agricultural entrepreneurs (young farmers) in carrying out their agricultural business activities. Like any other profession, farming requires high field experience. Young agricultural entrepreneurs (young farmers) are farmers who do not have high field experience. Most of them are novice farmers. Therefore, in carrying out their farming activities, they are encountered with obstacles which they think are something new. Their cosmopolitan attitude can encourage discovering solutions. They urged their parents, friends and explored other villages to find out new things. Some of them want to be more advanced in their farming than the surronding farmers. For that reason, they go to neighboring villages, kecamatan, kabupaten, visit exhibitions, and visit information source agencies to get information and innovation. Some of the things they are looking for are superior seeds, fertilizers, planting technology, commodity prices and markets. They seem to have the potential to be better farmers and are responsive to the latest technology as suggested Anwarudin et al. (2020a).

External factors cause a significant effect on the interest of young agricultural entrepreneurs (young farmers). It means that the greater the government support, the availability of infrastructure, agricultural extension, easy access to information, community leaders and production markets, the greater the interest of young agricultural entrepreneurs (young farmers). Government support for the growing interest of the younger generation to do business in agriculture has begun to be initiated. In 2013, the Ministry of Agriculture has issued Regulation of the Minister of Agriculture No. 07/Permentan/OT.140/1/2013 concerning Guidelines for the Development of Generation of the Young Agricultural Entrepreneurs (Young Farmers). The next few programs are the growth and development of young agricultural entrepreneurs that have been carried out in the last few years, such as the report from Anwarudin et al. (2020c) and Effendy et al. (2020). The program is rolled out based on Decree of the Minister of Agriculture of the Republic of Indonesia Number 
10/Kpts/SM.210///05/2019 concerning Guidelines for the Growth of Young Agricultural Entrepreneurs. The younger generation is provided with training and provided with business capital assistance. Of the large number of young generations, the portion targeted by the program is relatively small and limited only to alumni of universities majoring in agriculture and agricultural vocational high schools, but it has a positive effect on encouraging the younger generation to start businesses in the agricultural sector. Currently, the program of Ministry of Agriculture in collaboration with International Fund for Agricultural Development (IFAD) creating strong and quality millennial entrepreneurs through the Program of Youth Entrepreneurship and Employment Support Services (YESS). This YESS program has a broader target. It is unlimited to university graduates majoring in agriculture and agricultural vocational high schools. However, the target is also to the young generation in rural areas. Based on its location, this program is still limited to a few districts in Java and Kalimantan. However, the young agricultural entrepreneurs (young farmers) who were the respondents in this study did not enjoy the special programs for the younger generation. Yet, they experience the general programs aimed at farmers, such as assistance with agricultural tools and machineries as well as subsidized fertilizers.

Likewise, with infrastructure, the government through the ministry of agriculture has provided agricultural tools and machineries in sufficient quantities to farmers. The agricultural tools and machineries are then managed by an association of farmer groups or farmer groups or certain business groups like the Service Unit of Alsintan (Unit Pelayanan Jasa Alsintan; UPJA) depending on the location. Based on field observations, to operate these agricultural tools and machines, young agricultural entrepreneurs (young farmers) have more roles than older generations of farmers. In some locations, there are cases where older farmers hand over the management of agricultural tools and machineries to young agricultural entrepreneurs (young farmers). Several other findings show that young agricultural entrepreneurs (young farmers) are more inquisitive in managing their farms using agricultural tools and machineries. The use of agricultural tools and machineries makes land preparation faster, less tired and less burrowing with mud. Hence, agricultural mechanization has been able to attract young agricultural entrepreneurs (young farmers) to engage in agricultural activities to support research Anwarudin et al., (2020d). The use of agricultural tools and machineries in chili cultivation is not as high as in rice farming. Some of the agricultural tools and machineries used are tractors and water pumps. Tractors are used to cultivate the land, but it is only used for land that has been uncultivated for a certain period of time. Most of the land cultivation for chili cultivation is only by hoeing and making mounds. The water pump is used for watering chili plants. Especially, it is utilized when the dry season comes.

In the description of the role of agricultural extension officials, most of the young agricultural entrepreneurs (young farmers) rarely receive guidance from agricultural extension officials. Only a small number of young agricultural entrepreneurs (young farmers) have interacted simultaneously with agricultural extension officials. However, this interaction with agricultural extension officials has a positive effect and grows the interest of young agricultural entrepreneurs (young farmers). The role of agricultural extension officials is shown by their role as facilitators, communicators, dynamists and consultants (Helmi et al., 2019) and is expected to pay more attention to young agricultural entrepreneurs (young farmers) as the future generation of agriculture as stated Anwarudin et al. (2020b). Agricultural extension officials consist of extension officials from government, independent and private agency. In addition to the aforementioned roles, extension officials from government have the role of coordinating with those extension officials from independent and private agency. The extension officials from private agency are advanced farmers who are then asked to become extension officials for nearby farmers. Since independent extension officials are advanced farmers, the level of interaction with farmers is higher and the relationship is closer. To some extent, independent extension officials have been able to replace the very limited number of government extension officials. Independent extension officials often share their successful experiences with other farmers. Likewise, the success of independent extension officials as advanced farmers can be an example of success for young agricultural entrepreneurs (young farmers). For private extension officials, their role is still very limited. Activities having been carried out is the promotion of pesticides accompanied by technical application.

84 
Access to information and communication has a positive effect in developing the interest of young agricultural entrepreneurs (young farmers). It means that the more access of young agricultural entrepreneurs (young farmers) to agricultural information sources, the stronger their interest to pursue agricultural business. This study in line with Prawiranegara et al. (2016) and Ardelia et al. (2020) that Information and Communication Technology (ICT) plays a role in growing interest. Furthermore, young agricultural entrepreneurs (young farmers) need more detailed information so that they will look for a person to whom they will to ask questions and learn. The figure is an agricultural extension official. This is in line with Anwarudin et al. (2020b) stating that access to agricultural information and agricultural extension officials are complementary. The implication of these findings is that agricultural extension officials and all parties can collaborate in providing information digitally through ICT media so that it can be accessed by many people, including young agricultural entrepreneurs (young farmers).

Rural communities are still relatively obedient to the role of community leaders. They are seen as leaders for the citizens, worthy of emulation and follow their advice. The result of this study supports the finding of Ranzez et al. (2020) stating that the role of parents is proven in spreading the interest of their children to continue their parents' business as farmers. These findings also apply to the parents in this research site in addition to the role of other very helpful community leaders in the research site. Based on field observations, it is recognized that a special farmer group for young agricultural entrepreneurs (young farmers) can be formed because of the role of community leaders. Therefore, the role of community leaders must be optimized to be able to encourage parents and the younger generation to return to activities in the agricultural sector.

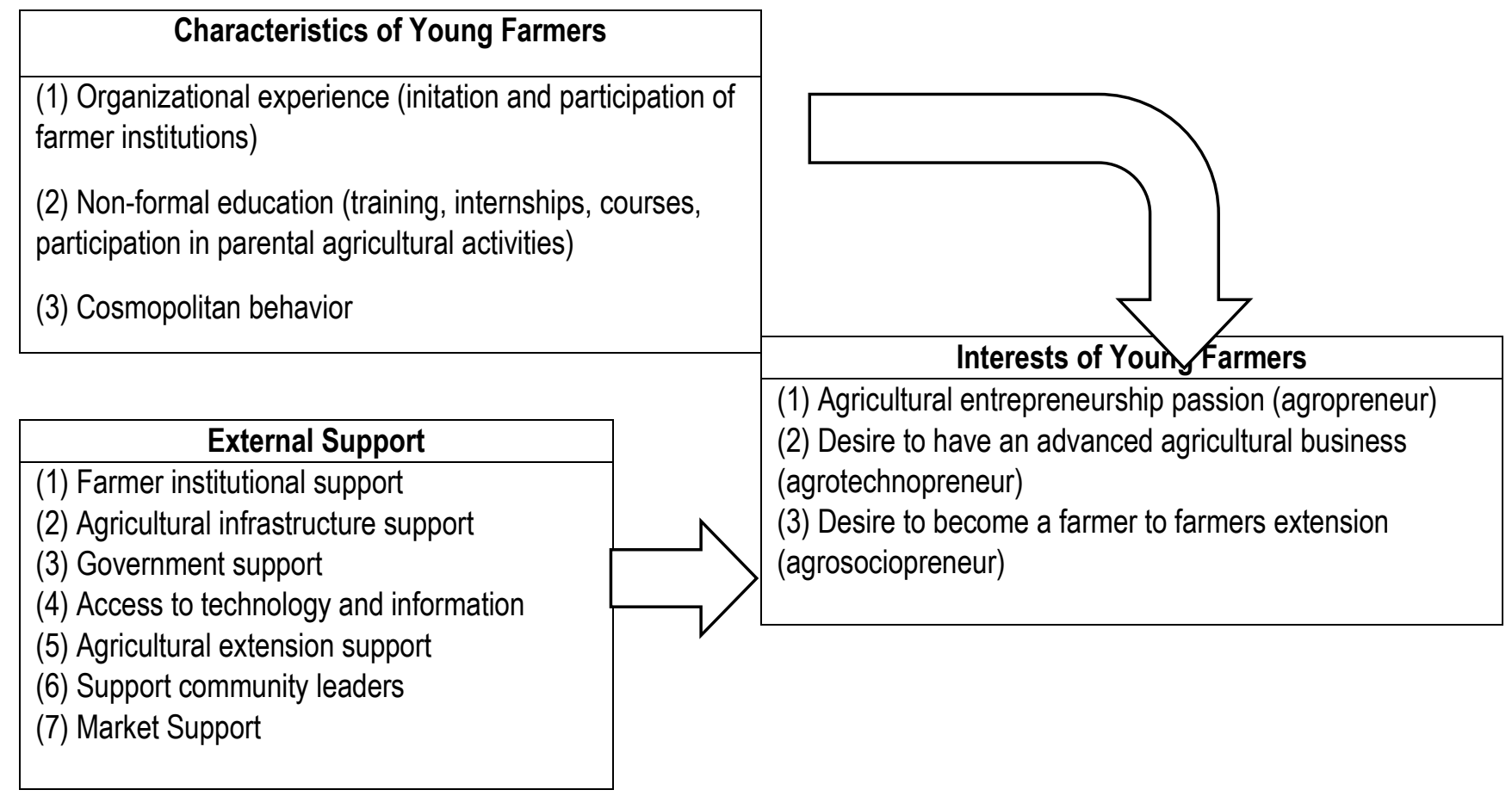

Figure 1 Approach to develop interest of young agricultural entrepreneurs (young farmers) in chili agribusiness.

The implications of this research are presented in Figure 1, the interest development of young agricultural entrepreneurs (young farmers) in chili agribusiness can be done by encouraging young agricultural entrepreneurs (young farmers) to have a passion for agricultural entrepreneurship (agropreneur), the desire to have their own advanced agricultural business (agrotechnopreneur) and the desire to share information with other farmers (agrosociopreneur). To develop the interest of these young agricultural entrepreneurs (young farmers), it is necessary to strengthen their individual characteristics through organizational experience. Young agricultural entrepreneurs (young farmers) must have a place to organize. In the New Order era, young 
agricultural entrepreneurs (young farmers) had a group called the "kelompok taruna tani." However, over time the farmer groups that have survived to this day are the "kelompok tani dewasa." This study found that organizational experience determines the interest of young agricultural entrepreneurs (young farmers). Therefore, young agricultural entrepreneurs (young farmers) must be accommodated in farmer groups, either by initiating and forming a special organization for young agricultural entrepreneurs (young farmers) or joining an existing farmer group. The involvement of young agricultural entrepreneurs (young farmers) in farmer groups requires the efforts of farmer group administrators and agricultural extension officials (Anwarudin et al., 2020b).

Furthermore, strengthening the individual characteristics of young agricultural entrepreneurs (young farmers) can be done through non-formal education, namely training, internships, courses and participation in family farming businesses. Training for young agricultural entrepreneurs (young farmers) can be entrepreneurship and technical training. Internship activities have proven to be effective in forming new farmers. An example of an internship is a Japanese internship where some of the alumni have become advanced farmers, as reported Harniati \& Anwarudin (2018). Likewise, parents can play an optimal role in instilling respect and socialization by involving their children in family farming. A small example carried out by several families is involving children in planting chilies by utilizing their yard. This activity supports reports from Nita et al., (2020) stating that the involvement of the younger generation in the use of their yard is effective in growing the interest of the younger generation.

The development of interest in young agricultural entrepreneurs (young farmers) can also be done by optimizing external support: farmer institutional support, support for the availability of agricultural infrastructure, government support, access to technology and information, the role of agricultural extension officials, community leaders and markets. Farmer institutions are a forum for farmers, including young agricultural entrepreneurs (young farmers), to share information, receive guidance and improve their bargaining position (Harniati \& Anwarudin, 2018a). Farmer institutions can be in the form of farmer groups and association of farmer groups. The existence of farmer institutions specifically for young agricultural entrepreneurs (young farmers) is still limited in quantity. On the other hand, based on field observations, most of the young agricultural entrepreneurs (young farmers) have not been involved in the existing farmer groups. Therefore, the development of farmer institutions is sought to be able to embrace young agricultural entrepreneurs (young farmers) as members. With the involvement of young agricultural entrepreneurs (young farmers) in the organization can increase the interest of young agricultural entrepreneurs (young farmers) in agriculture as reported by Junaidi et al., (2020).

Agricultural extension officials consist of extension officials from government, independent and private agency. Agricultural extension officials can try making young agricultural entrepreneurs (young farmers) as target of agricultural extension. This is because based on observations in the field, the target of extension is still struggling with elderly farmers. Government extension officials can act as facilitators, communicators, motivators, consultants and coordinate with independent and private extension officials. Independent extension officials are advanced farmers in their domicile locations. The existence of independent extension officials can be optimized for their role as a successful example for young agricultural entrepreneurs (young farmers). Findings in the field, many young people become interested in agriculture after witnessing the success of advanced farmers. Therefore, government extension officials can coordinate with advanced farmers as independent extension officials to encourage them to share knowledge and experiences with young agricultural entrepreneurs (young farmers).

Community leaders who become formal and informal leaders in the village must be able to perceive and express the positive side of the agricultural sector. It is because most young agricultural entrepreneurs (young farmers) in rural areas still regard community leaders as role models. Therefore, all thoughts and actions of community leaders become the center of attention of young agricultural entrepreneurs (young farmers). When 
several community leaders voiced their desire to work in the city, many young people in the village went to the city to work. On the other hand, when community leaders speak out for village development, the younger generation mostly lives in the village and works in the rice fields and fields. The attention of community leaders is very important in supporting the creativity of the younger generation. One of the special farmer groups for young agricultural entrepreneurs (young farmers) encountered in this study cannot be separated from the support and role of community leaders.

Market support in the form of selling price information, product demand volume and consumer quantity determine the interest of young agricultural entrepreneurs (young farmers). Therefore, the implication of this research is that information on the selling price of chili must be more transparent. The selling price of chili can be maintained stable and profitable for farmers. Transparency must also exist in information on the volume of chili demand and the quantity of consumers, both in location and time. The information must be fast and accurate so that chili farmers can prepare and schedule harvest times, the means of transportation used and the choice of locations for marketing purposes.

\section{CONCLUSION}

The interest of young agricultural entrepreneurs (young farmers) in Kabupaten Garut is at a moderate level. The average age of young agricultural entrepreneurs (young farmers) is 31.47 years; the majority have elementary school education; most of them have never been involved in organizations and have never had internships/courses/training. However, their cosmopolitan behavior is in the high category. The interest of young agricultural entrepreneurs (young farmers) is affected by organizational experience, nonformal education, cosmopolitan and external factors including government support, availability of infrastructure, agricultural extension, easy access to information, community leaders and production markets. This study recommends that young agricultural entrepreneurs (young farmers) often obtain non-formal education. The interest development of young agricultural entrepreneurs (young farmers) in chili agribusiness can be done by encouraging young agricultural entrepreneurs (young farmers) to have a passion for agricultural entrepreneurship (agropreneur), the desire to have their own advanced agricultural business (agrotechnopreneur) and the desire to share information with other farmers (agrosociopreneur).

\section{REFERENCES}

Anwarudin, O. (2021). Regenerasi Petani melalui Transformasi Agropreneur Muda. Disertasi. IPB University.

Anwarudin, O., \& Dayat, D. (2019). The effect of farmer participation in agricultural extension on agribusiness sustainability in Bogor, Indonesia. International Journal of Multicultural and Multireligious Understanding (IJMMU), 6(3), 1061-1072. https://doi.org/http://dx.doi.org/10.18415/ijmmu.v6i3.1028

Anwarudin, O., \& Haryanto, Y. (2018). The role of farmer-to-farmer extension as a motivator for the agriculture young generation. International Journal of Social Science and Economic Research (IJSSER), 3(1), 428-437.

Anwarudin, O., Sumardjo, S., Satria, A., \& Fatchiya, A. (2019). Factors influencing the entrepreneurial capacity of young farmers for farmer succession. International Journal of Innovative Technology and Exploring Engineering, 9(1), 1008-1014. https://doi.org/10.35940/ijitee.A4611.119119

Anwarudin, O., Sumardjo, S., Satria, A., \& Fatchiya, A. (2020a). Kapasitas kewirausahaan petani muda dalam agribisnis di Jawa Barat. Jurnal Penyuluhan, 16(02), 267-276. https://journal.ipb.ac.id/index.php/jupe/article/view/31039

Anwarudin, O., Sumardjo, S., Satria, A., \& Fatchiya, A. (2020b). Peranan penyuluh pertanian dalam mendukung keberlanjutan agribisnis petani muda di Kabupaten Majalengka. Jurnal Agribisnis Terpadu, 13(1), $17-36$. 
Anwarudin, O., Sumardjo, S., Satria, A., \& Fatchiya, A. (2020c). Proses dan pendekatan regenerasi petani melalui multistrategi di Indonesia. Jurnal Litbang Pertanian, 39(2), 73-85. https://doi.org/10.21082/jp3.v39n2.2020.p73-85

Anwarudin, O., Sumardjo, S., Satria, A., \& Fatchiya, A. (2020d). Support of agriculture extension on improving entrepreneurship capacity of young farmers. Journal of the Social Sciences, 48(2), 1855-1867.

Ardelia, R., Anwarudin, O., \& Nazaruddin, N. (2020). Akses teknologi informasi melalui media elektronik pada Petani KRPL. Jurnal Triton: Pertanian, 11(1), 24-36.

Dayat, D., \& Anwarudin, O. (2020a). Faktor-faktor penentu partisipasi petani dalam penyuluhan pertanian era otonomi daerah di Kabupaten Bogor. Jurnal Agribisnis Terpadu, 13(2), 167-186. https://doi.org/10.33512/jat.v13i2.9865

Dayat, D., \& Anwarudin, O. (2020b). The effect of entrepreneurship capacity on sustainability of young farmers agribusiness. Journal of the Social Sciences, 23(1), 123-134.

Dayat, D., Anwarudin, O., \& Makhmudi, M. (2020). Regeneration of farmers through rural youth participation in chili agribusiness. International Journal of Scientific \& Technology Research, 9(3), 1201-1206.

Effendy, L., Maryani, A., \& Azie, A. Y. (2020). Factors affecting rural youth interest in agriculture in Sindangkasih Ciamis District. Jurnal Penyuluhan, 16(2), 277-288.

Hamdana, A., Kusnadi, D., \& Harniati, H. (2020). Keberdayaan petani dalam penerapan budidaya padi sawah sistem jajar legowo di Desa Babakankaret Kecamatan Cianjur Kabupaten Cianjur Provinsi Jawa Barat. Jurnal Inovasi Penelitian, 1(4), 747-757.

Harniati, H., \& Anwarudin, O. (2018a). Strategy to improve the performance of farmer economic institution in agribusiness at Sukabumi, Indonesia. International Journal of Recent Scientific Research (IJRSR), 9(3), 24712-24718. https://doi.org/10.24327//JRSR

Harniati, H., \& Anwarudin, O. (2018b). The interest and action of young agricultural entrepreneur on agribusiness in Cianjur Regency, West Java. Jurnal Penyuluhan, 14(1), 189-198. https://doi.org/10.25015/penyuluhan.v14i1.18913

Helmi, Z., Haryanto, Y., Anwarudin, O., \& Trisnasari, W. (2019). Paradigma Penyuluhan di Era Teknologi Informasi (1st ed.). Tohar.

Junaidi, A. J., Anwarudin, O., \& Makhmudi, M. (2020). Dinamika kelompoktani terhadap minat generasi muda pada kegiatan usaha tani padi (Oriza sativa) di Kecamatan Gantar Kabupaten Indramayu. Jurnal Inovasi Penelitian, 1(3), 501-511.

Liani, F., Sulistyowati, D., \& Anwarudin, O. (2018). Perspektif gender dalam partisipasi petani pada Kawasan Rumah Pangan Lestari (KRPL) tanaman sayuran di Kecamatan Kersamanah Kabupaten Garut Provinsi Jawa Barat. Jurnal Penyuluhan Pertanian, 13(1), 21-32.

Maryani, A., Effendy, L., \& Windi, D. (2020a). Farmers' preferences for citrus agribusiness in Samarang Subdistrict, Garut, West Java. International Journal of Multicultural and Multireligious Understanding, 7(10), 770-778.

Maryani, A., Effendy, L., \& Windi, D. (2020b). Farmers' Preferences for Citrus Agribusiness in Samarang Subdistrict, Garut, West Java. International Journal of Multicultural and Multireligious Understanding, 7(10), 770-778. 
Nazaruddin, N., \& Anwarudin, O. (2019). Pengaruh penguatan kelompok tani terhadap partisipasi dan motivasi pemuda tani pada usaha pertanian di Leuwiliang, Bogor. Jurnal Agribisnis Terpadu, 12(1), 1-14.

Ningsih, F., \& Sjaf, S. (2015). Faktor-faktor yang menentukan keterlibatan pemuda pedesaan pada kegiatan pertanian berkelanjutan. Jurnal Penyuluhan, 11(1), 23-37. https://doi.org/10.25015/penyuluhan.v11i1.9929

Nita, D. R., Anwarudin, O., \& Makhmudi, M. (2020). Regenerasi petani melalui pengembangan minat pemuda pada kegiatan KRPL di Kecamatan Sukaraja Kabupaten Bogor. Jurnal Penyuluhan Pertanian, 15(1), 8-22.

Pradiana, W., Anwarudin, O., \& Maryani, A. (2020). Determining factors of the development of agricultural extension office as a knot for coordinating agricultural development. International Journal of Scientific \& Technology Research, 9(3), 3766-3733.

Prawiranegara, D., Sumardjo, S., Lubis, D. P., \& Harijati, S. (2016). Effect of information quality based on cyber toward vegetable farmers capability to manage innovation in west java. Sosiohumaniora, 18(2), 166172.

Qintamy, R. A., Harniati, H., \& Kusnadi, D. (2020). Tingkat keberdayaan petani dalam penerapan Low External Input Sustainable Agriculture (LEISA) pada budidaya ubi jalar di Kecamatan Cilawu Kabupaten Garut. JIA (Jurnal IImiah Agribisnis) : Jurnal Agribisnis Dan IImu Sosial Ekonomi Pertanian, 5(4), 131-140. https://doi.org/10.37149/jia.v5i4.13046

Ranzez, M. C., Anwarudin, O., \& Makhmudi, M. (2020). Peranan orangtua dalam mendukung regenerasi petani padi (Oryza sativa I) di Desa Srikaton Kecamatan Buay Madang Timur. Jurnal Inovasi Penelitian, 1(2), 117-127.

Wardani, W., \& Anwarudin, O. (2018). Peran penyuluh terhadap penguatan kelompok tani dan regenerasi petani di Kabupaten Bogor Jawa Barat. Jurnal TABARO, 2(1), 191-200.

Wiyono, S., Sangaji, M., Ahsan, Ulil, M., \& Abdullah, S. (2015). Regenerasi petani, faktor-faktor yang mempengaruhi minat menjadi petani pada keluarga petani padi dan hortikultura. Laporan Kajian Koalisi Rakyat Untuk Ketahanan Pangan, 1-46. 